\title{
Piaget'nin Genetik Epistemolojisi, Carnap ve Mantık ile Matematiğin Temelleri Sorunu
}

\author{
Piaget's Genetic Epistemology, Carnap and Logic and the Problem of the \\ Foundations of Mathematics
}

\begin{abstract}
Ali Bilge ÖZTÜRK*
Öz: Jean Piaget yalnızca bilişsel gelişim psikolojisinin bir öncüsü değildi. Aynı zamanda yeni bir epistemoloji yaklaşımı olan genetik epistemoloji yaklaşımın da geliştiricisiydi. Genetik epistemoloji yaklaşımı, yani epistemolojik sorunlara genetik yaklaşım, psikolojiye daha yakın bir epistemolojiyi teklif eder. Piaget'ye göre bu yeni yaklaşımı geliştirmesinin gerekçesi, bilgi kuramcılarının bilimsel verileri, daha özelde empirik psikolojinin verilerini yeterince göz önünde bulundurmamasıdır. Böylece epistemolojinin sorunlarına getirilen klasik çözüm önerileri sıklıkla spekülatif niteliklidir. Piaget'nin bu eleştirisine gerekçe olarak sunduğu en önemli örneklerden biri mantıksal pozitivistlerin mantığın ve matematiğin dile veya dilsel uzlaşıma dayandığı savıdır. Piaget'ye göre bu sav bilimsel verilerle çelişen spekülatif nitelikli bir iddiadan başka bir şey değildir. Bu çalışmada, Piaget'nin mantıksal pozitivistlere yönelttiği bu eleştiri değerlendirilmekte ve haksız olduğu savunulmaktadır. Bunun nedeni mantıksal pozitivistlerin söz konusu tezinin bir normatif epistemoloji tezi olduğu ve genetik epistemoloji yaklaşımının, mantığın ve matematiğin temelleri sorununun normatif boyutunu göz önünde bulundurmamış olmasıdır.
\end{abstract}

Anahtar sözcükler: Epistemoloji, Normatiflik, Genetik Epistemoloji, Matematik, Mantık

\begin{abstract}
Jean Piaget was not only a pioneer of cognitive developmental psychology. He was also the founder of genetic epistemology, which is a new approach to epistemology. The genetic epistemology approach, or the genetic approach to epistemology, offers a kind of epistemology that is closer to psychology. The justification for this new approach, according to Piaget, is the low usage of data provided by empirical psychology in epistemological inquiries. In this way, classical solutions to epistemological problems are generally speculative in nature. One of the examples, which Piaget shows as a justification for this claim, is the logical positivist thesis that logic and mathematics depend upon or are derived from the language or from linguistic conventions. According to Piaget, this thesis is nothing but a speculative claim contradicting scientific data. In this study, this criticism made by Piaget against logical positivism is analyzed and it is argued that it is unjustified. This is because the thesis of logical positivism is a normative thesis in nature and the genetic epistemology approach misses the normative aspect of the problem of the foundations of logics and mathematics.
\end{abstract}

Keywords: Epistemology, Normativity, Genetic Epistemology, Mathematics, Logic

Jean Piaget açıkça çağdaş psikolojinin önemli öncülerinden biriydi. Psikoloji alanında yaşamı boyunca sürdürdüğü çalışmalar, insanın bilişsel gelişimine dair önemli bir model sundu. Böylece Piaget'nin bilişsel gelişim kuramı, gelişim psikolojisi literatürün ayrılmaz bir parçası haline gelerek sayısız psikolojik araştırmanın konusunu oluşturdu. Ancak Piaget'nin önemli bir

\footnotetext{
* Arş. Gör., Akdeniz Üniversitesi, Edebiyat Fakültesi, Felsefe Bölümü, Antalya. alibilgeozturk@akdeniz.edu.tr
} 
özelliği kendisine dair araştırmalarda yeterince ilgi görmemiştir: Esasta Piaget'nin hayatı boyunca insan bilişinin gelişimine dair çalışmalarını motive eden sorunlar, çoğunlukla felsefe, daha özelde epistemoloji kökenliydi. Piaget çağdaş felsefede sıkça tartışılan pek çok epistemolojik sorundan ve bu sorunlara getirilen çeşitli çözüm önerilerinden açıkça haberdardı. $\mathrm{Bu}$ sorunlardan bazıları şöyle sıralanabilir: Bilgimizin kaynağı nedir? Doğuştan getirdiğimiz birtakım kavramlar veya bilgiler bulunmakta mıdır? Başta sayılar olmak üzere matematiksel nesnelerin kökeni nedir? Aritmetiğin ve geometrinin temelleri nedir? Mantıksal düşünmenin kaynağı nedir? Bilgi, daha özelde bilimsel bilgi nasıl oluşur? Böylece Piaget bilgi felsefesi, mantık felsefesi, matematik felsefesi ve bilim felsefesinin konu alanına giren pek çok sorundan haberdardı ve çalışmalarını arka planda hep bu sorunlar çerçevesinde sürdürme eğiliminde oldu.

Diğer taraftan Piaget epistemolojinin bu tartışmalı konularına getirilen çözüm önerilerine dair bir bilimsel memnuniyetsizlik içindeydi. Bu durum onun çağdaş epistemoloji literatürüne karşı meta-epistemolojik bir tavır almasına yol açmıştır. Sözü edilen meta-epistemolojik tavır, Piaget'nin olgunluk dönemi çalışmalarında, psikolojinin empirik kaynaklarına dayanan yeni bir epistemolojik yaklaşım geliştirilmesi gerektiği fikri olarak açığa çıkar. Psikolojinin empirik verilerinin epistemolojik soruşturmaların ayrılmaz bir parçası olduğunu ileri süren bu yaklaşımı Piaget genetik epistemoloji olarak adlandırır.

Bu çalışmada Piaget'nin, Rudolf Carnap ile mantıksal pozitivistlere ve onların mantığın ve matematiğin dile dayandığ 1 tezine yönelttiği eleştiri değerlendirilmektedir. Çünkü her ne kadar Piaget epistemolojinin sorunlarına getirilen klasik çözüm önerilerine dair bilimsel memnuniyetsizliğini savunmak için birtakım örnekler sunmuş olsa da, bu örneklerden en açık olanı mantıksal pozitivistlerin mantığın ve matematiğin dile dayandığı tezidir. Piaget'ye göre söz konusu tez, psikolojinin bilimsel verileriyle düpedüz çelişen bir tezdir ve mantıksal pozitivistlerin konuya yaklaşım tarzı, terk edilmesi gereken klasik yaklaşımın çok açık bir örneğidir. Bu noktadan hareketle Piaget'ye göre söz konusu tartışma ancak genetik epistemoloji yaklaşımıyla çözülebilecek bir tartışmadır. Böylece mantıksal pozitivistlerin söz konusu tezi Piaget'nin yalnızca klasik yaklaşımlardan duyduğu bilimsel memnuniyetsizliği temellendirmek için değil, aynı zamanda kendisinin ortaya koyduğu genetik epistemoloji yaklaşımının başarısını da temellendirmek için sunmuş olduğu bir örnektir. Ancak bu çalışmada savunulmaya çalışılan şey, Piaget'nin mantıksal pozitivistlere yönelttiği söz konusu eleştirisinde esasta haksız olduğudur. Bunun nedeni mantıksal pozitivistlerin söz konusu tezinin betimsel epistemolojiye değil, normatif epistemolojiye ait bir tez olduğu ve genetik epistemoloji yaklaşımının ise epistemolojinin normatif boyutunu gözden kaçırmış olmasıdır.

Çalışma bu noktayı göstermeye yönelik üç ayrı bölümden oluşmaktadır. Birinci bölümünde Piaget'nin genetik epistemoloji yaklaşımı hakkında mümkün olduğunca geniş bir kavrayış kazanmak için klasik epistemoloji soruşturmalarının niteliği ve ardından epistemoloji-psikoloji ilişkilerine dair çeşitli görüşler hakkında bazı açıklamalar yapılmaktadır. Ardından Piaget'nin epistemoloji yaklaşımının nasıl bir yaklaşım olduğu ve bu klasik yaklaşımlarla karşılaştırıldığında nasıl bir konuma denk geldiği tartışılmaktadır. Bu tartışma sonucunda Piaget'nin genetik epistemoloji yaklaşımının nitelik olarak bir tür ılımlı psikolojizm örneği olduğu savunulmaktadır. İkinci bölümde Piaget'nin kendi genetik epistemoloji yaklaşımının başarısını savunmak amaciyla Carnap ve mantıksal pozitivistlere yönelttiği eleştirisi mümkün olduğunca geniş bir şekilde incelenmektedir. Üçüncü bölümde ise incelenen söz konusu eleştiri değerlendirilmekte ve bu değerlendirme sonucunda Piaget'nin eleştirisinde haksız olduğu, çünkü mantık ile matematiğin temelleri sorununun normatif boyutunu gözden kaçırdığı gösterilmeye çalışılmaktadır. 
I.

Epistemoloji veya bilgi felsefesi veya bilgi kuramı, iyi bilindiği gibi bilgi kavramına dair bazı önemli sorulara yanıt bulmayı hedefleyen bir alandır: Bilgi nedir? Bilginin kaynağı nedir? Bilginin yapısı nedir? Bilginin değeri nedir? vb. Buna ek olarak epistemoloji bu tür ana sorunlar ile bir şekilde bağlantılı olan bazı alt sorulara da yanıt vermeyi amaçlar. Örneğin insan bilişinin doğuştan birtakım kavramlara sahip olup olmadığı sorusu, birtakım kanaatlerimiz için deneyden bağımsız olarak (ve elbette bilginin doğasına uygun) gerekçe bulup bulamayacağız sorusu ve benzeri sorular bilginin kaynağı sorunu ile ilişkili bir takım alt sorulardır. Benzer şekilde delillerimiz ile inançlarımız arasındaki mantıksal (tümevarımlı, tümdengelimli vb.) bağlantının ne olduğu sorusu, bilgi sistemimizde birtakım kanaatlerimizin terk edilemez olup olmadığı ve benzeri sorunlar bilginin yapısına sorununa dair bazı alt sorulardır. Kısaca, epistemolojinin temel sorunları, bu sorunlarla bir şekilde ilişkili alt sorular etrafında çözüm aranan sorunlardır.

Fiilen olan ile ideal olarak olması gereken arasındaki ayrım, tarihsel olarak epistemolojik sorunlara dair iki farklı yaklaşımın geliştirilmesine yol açmıştır. Örneğin insanların neye bilgi dediği ve neye bilgi demesi gerektiği, yani hangi epistemik şartları sağlayan kanaatlerinin bilgi olduğunu fiilen ileri sürdüğü ve hangi epistemik şartları sağlayan kanaatlerinin bilgi olduğunu ileri sürmesi gerektiği farklı konulardır. Benzeri şekilde insanların delilleri ile kanaatleri arasındaki ilişkiyi nasıl kurduğu konusu ile nasıl kurması gerektiği konusu birbirinden farklı konulardır. Yine benzer şekilde insanların bilgi sisteminde birtakım kanaatlerini terk edilemez görüp görmediği konusu ile bir kural olarak bu şekilde görüp görmemeleri gerektiği konusu farklı konulardır. Birinci türdeki sorulara yanıt ararken yapılan sorgulama betimleyici epistemoloji (İng. descriptive epistemology) olarak anılırken, ikinci türdeki sorulara yanıt verirken yap1lan sorgulama normatif epistemoloji (İng. normative epistemology) olarak anılir.

Epistemolojik soruşturmalar, bilimsel alanlara temel olan soruşturmaların çoğunda olduğu gibi ilk olarak felsefe içinden gelişmiştir. Filozoflar ise geleneksel olarak bilgi kavramını normatif bir kavram olarak değerlendirmiştir. Diğer bir deyişle çoğu filozofa göre bilgi, kişinin spontane şekilde sahip olduğu değil ancak bir takım ödev ve sorumlulukları yerine getirdiğinde sahip olduğunu iddia edilebileceği bir şeydir. Bu temelde filozoflar epistemolojinin temel sorunlarına normatif bir çerçeveden yanıt vermeye çalışmıştır ki bu durum epistemolojinin tarihsel olarak betimleyici değil normatif karakterli bir alan haline gelmesine neden olmuştur. Örneğin bir filozof bilginin ne olduğunu sorguladığında sorguladığı şey insanların genel olarak hangi şartları sağlayan kanaatlerine bilgi dediği değil, bilgi statüsündeki bir kanaatin hangi şartları sağlaması gerektiğidir. Yine benzer şekilde bir filozof delil ile inanç/kanaat veya belki de kuram arasındaki ilişkiyi sorguladığında, sorguladığı şey insanların genel olarak inançlarını/kanaatlerini nasıl delillendirdiği değil, nasıl delillendirmesi gerektiğidir. Bu nokta geleneksel epistemolojinin çok belirgin bir özelliğidir.

Epistemolojiye dair ifade edilmesi gereken başka bir durum, filozofların epistemolojiye temel olan bu tür sorgulamaları genellikle doğrudan yapmamış olmasıdır. Esasta düşünce tarihi boyunca epistemolojik tartışmalar çoğu zaman belirli felsefi gündemlerle bağdaşacak şekilde yapılmıştır. Diğer bir deyişle epistemolojik tartışmaların her zaman bir felsefi gündemi olmuştur. Şimdi, modern epistemolojiye ve 20. yüzyılın ilk dönemindeki epistemolojiye bu çerçevede bakılırsa, epistemolojinin gündemini belirleyen asıl çerçevenin Kartezyen "ilk felsefe" çerçevesi olduğu rahatlıkta görülebilir. Bu çerçeveye göre genel olarak felsefe, daha özelde epistemoloji, bütün bilimlere göre öncelikli, ayrıcalıklı ve bütün bilimlerden bağımsız bir konumdadır. $\mathrm{Bu}$ öncelikli ve ayrıcalıklı konum içerisinden epistemoloji, sağlam/kesinlikli temellerle güvence altına alınmış bir bilim modeli oluşturmalıdır. Temelleri sağlam, düzgün bir bilim faaliyeti 
ancak böyle bir model oluşturulup, bu model dikkatlice uygulanırsa mümkündür. Hilary Kornblith'in de çok güzel ifade ettiği gibi:

Klasik anlayışta, bir kuram epistemolojik inançlarımıza nasıl ulaşmamız gerektiğini bize açıklamalıdır; çevremizdeki dünya hakkındaki herhangi bir şeye ancak böyle bir kuram geliştirildiğinde ve bu kuram uygulandlğında akla uygun şekilde inanabiliriz. Dolayısılla klasik anlayışa göre epistemolojik bir kuram herhangi bir bilimsel kuramsallaştırmadan bağımsız ve ona öncelikli şekilde geliştirilmelidir; düzgün bir bilimsel kuramsallaştırma ancak böyle bir kuram geliştirildikten ve uygulandıktan sonra ortaya çıkar (Kornblith 2010, 543).

Böylece bu çerçeveden hareketle Descartes'tan başlayarak 20. yüzyılın ilk yarısına (ve hatta sonrasına) kadar epistemoloji, bilgiye sağlam temeller aramak gayesiyle pek çok soruşturmaya zemin oluşturmuştur: Dış dünyanın varlığı sorunu, zihin beden düalizmi, belleğin güvenilirliği sorunu, diğer zihinler sorunu (İng. problem of other minds), tümevarım sorunu, nedensellik fikrinin kökeni sorunu, doğa yasalarının statüsü sorunu, mantığın ve matematiğin temelleri sorunu, vb.

Son olarak meta-epistemolojik sorunlardan bahsederken ise epistemolojinin konusu, yöntemi, amacı gibi epistemolojiye dair üst tartışmalar akla gelmektedir. Bir düşünürün epistemolojik sorunları çözmek için kullanması gereken yöntemlerin ve yaklaşımın ne olması gerektiği, epistemolojik sorgulamanın amacının ne olduğu ve benzeri sorulara verilen yanıtlar metaepistemolojik yaklaşımımızı belirler.

Şimdi, çağdaş epistemolojik tartışmalara bu kavram şeması çerçevesinde yaklaşıldığında kolayca tespit edilebilecek bir durum şudur ki, bu tartı̧̧malarda, özellikle yirminci yüzyılın başındaki tartışmalarda, en belirgin meta-epistemolojik yaklaşımlardan biri anti-psikolojizm adını verebileceğimiz bir yaklaşımdı. Bu yaklaşım kabaca şuna benzer şekilde ifade edilebilir:

Anti-psikolojizm: Epistemolojinin sorunlarının çözümünde bilişsel süreçlerin işleyişine dair betimsel psikolojik açıklamalar ya yetersizdir (1lımlı anti-psikolojizm) ya da gereksizdir (kat1 anti-psikolojizm).

Böyle bir meta-epistemolojik kanaat çağdaş bilgi kuramcılarının çoğunda, genelde örtük olarak veya bazen açık şekilde, 1lımlı veya katı formlarda paylaşılmıştır. Şimdi, bilgi kuramcılarını böyle bir kanaate götüren pek çok neden, biyografik veriler sşı̆̆ında tek tek sıralanabilir; ancak özellikle şunu not etmek gerekiyor. Çoğu bilgi kuramcısı doğruluğu bilginin gerek şartlarından biri sayar ve doğruluğun mahiyetine dair soruşturmayı ise psikolojik soruşturmayı aşan bir soruşturma türü olarak görür. $\mathrm{Bu}$ temelde bu bilgi kuramcılarına göre, bir kişiyi belirli bir kanaatinde (gündelik, bilimsel vb.) haklı kılacak ve bu kanaatinin bir bilgi örneği olduğunu ileri sürebilmesini sağlayacak unsurlar neyse bu unsurlar bu kanaati oluşturan psikolojik şartlardan (örneğin zihninin psikolojik kuruluşu, inanç oluşturma mekanizmalarının nasıl işlediği, kişinin psikolojik beklentileri, vb.) çoğunlukla veya tamamen bağımsızdır. Bu bağlamda örneğin Bertrand Russell'ın bir 1lımlı anti-psikolojizm örneği olarak değerlendirilebilecek şu görüşünü hatırlayabiliriz:

Bilgi kuramı gerçekte psikolojiden farklıdır fakat daha karmaşıktır: Çünkü inanca dair yalnızca psikolojinin söylemesi gerektiği şeyleri içermez ancak buna ek olarak, bilginin yalnızca doğru olana inanma olmasından hareketle, doğruluk ve yanlışlık ayrımını da içerir (Russell 1904, 205). 
Diğer taraftan şunu belirtmek gerekiyor ki, 20. yüzyılın başlarında epistemolojiye hakim olan bu anti-psikolojistik tavır, özellikle yüzyılın ortalarından itibaren yumuşamaya başlamıştır: Epistemolojik soruşturmalarda meslekten psikologların empirik verilerinin de dikkate alınması gerektiği fikri özellikle 20. yüzyılın ortalarından itibaren gittikçe güçlenmeye başlamıştır. Hatta örneğin bu yumuşama, bazı filozoflarda, bilgi kuramının tamamen psikolojiye dayanması gerektiği şeklinde ifade edilebilecek bir tür katı psikolojizme dahi dönüşmüştür. Bu noktada Quine'ın "doğallaştırılmış epistemoloji”" (İng. naturalized epistemology) yaklaşımını hatırlamakta fayda bulunuyor. "[B]ilimsel kesinlik için bilimsel yöntemin kendisinden daha sağlam bir Kartezyen temel rüyasını reddeden büyük azınlık veya küçük çoğunluktanım" görüşünü paylaşan Quine (1992, 19), epistemolojinin (psikoloji de dahil olmak üzere) bütün bilimlerden bağımsız, bilimlere göre öncelikli ve ayrıcalıklı bir felsefi konumda olduğu fikrini reddetmişti. Böylece Quine, epistemolojinin amacının, bilim öncesi bir konumdan, bilime sağlam zeminler bulmak olduğu şeklindeki klasik Kartezyen meta-epistemolojik yaklaşımı da reddetmişti. Bunun yerine epistemolojik sorgulamanın bilimle eşzamanlı, bilimin bizzat kendi içinden ve bilimin mümkün bütün dallarından elde edilen verileri de serbestçe kullanarak yapılması gereken bir sorgulama haline getirilmesi gerektiğini savunmuştu. Bu amaca yönelik olarak Quine 1960'ların sonlarına doğru, epistemolojiyi felsefenin sınırlarından çıkarıp bilimin, daha özelde ise empirik psikolojinin bir alt dalı olarak konumlandırmaya çalışarak bir tür katı psikolojizm örneği sunmuştu. Kendi ifadesiyle:

Epistemoloji veya benzeri bir şey, temelde psikolojinin ve dolaylstyla doğa biliminin bir bölümü olarak yer alır. Epistemoloji bir doğa fenomenini yani fiziksel bir insan öznesini araştırır. Bu insan öznesi, deneyimle denetlenen belirli bir girdiyi -örneğin çeşitli frekanslardaki ışın parçalarını- alır ve zamanı gelince çevresindeki üç boyutlu dünyanın betimlemesini ve tarihini bir çıktı olarak verir. Az seviyede girdi ile yığınla çıktı arasındaki bu ilişsi bizi araştırmaya teşvik eden bir sebeptir ve bu sebep, epistemolojiyi harekete geçiren sebepler olan delillerin kuramlarla ilişkisini görme ile doğa kuramlarının eldeki delilleri nasıl aştı̆̆ını görme gibi sebeplerle kismen aynıdı"” (Quine 1969, 82-83). (...) "Eski epistemolojinin doğa bilimini bir anlamda kapsaması hedeflenmişti; epistemoloji duyu verileri temelinde doğa bilimini kurabilmeliydi. Bu yeni haliyle epistemoloji, aksine doğa bilimi içinde, psikolojinin bir bölümü olarak kapsanır (Quine 1969, 83).

Şimdi, okuyucunun da kolayca fark edebileceği gibi, yirminci yüzyılın başında bilgi kuramının "doğruluk ve yanlışlık" ayrımını da içerdiği için tamamen psikolojiye indirgenemeyeceğini ve mantıksal analizin en önemli yöntem olduğunu ileri süren Russell'ın 1lımlı anti-psikolojik tavrı ile yirminci yüzyılın ortalarından sonra bilgi kuramının tamamen bilimin, daha özelde psikolojinin bir alt dalı olarak konumlandırılması gerektiğini savunan Quine'ın katı psikolojistik tavrı arasında büyük bir tavır değişimi gözlenmektedir. İşaret edilen bu tavır değişikliğinin nedenleri olarak elbette birtakım unsurlar akla getirilebilir. Örneğin belki psikoloji bilimin ilerlemesi sonucu psikolojiye dair artan bir bilimsel memnuniyetten söz edilebilir. Benzer şekilde, bilgi kuramsal sorunları klasik a priori felsefi refleksiyonlar yoluyla çözme girişimine dair artan bir memnuniyetsizlikten ve dolayısıyla yeni yöntemler arama girişimlerinden bile söz edilebilir. Diğer taraftan bu çalışma açısından önemli olan şey psikolojinin verilerine dair söz konusu tavır değişikliğinin nedenlerini ortaya çıkarmak değil, epistemoloji-psikoloji ilişkilerine dair çeşitli düşünürlerin, çeşitli zamanlarda, çeşitli gerekçelerle, çeşitli psikolojistik veya anti-psikolojistik 
karakterli modeller ve tutumlar ortaya koymuş olduklarını not etmektir. Şimdi artık, bu çok genel notların sağladığı arka plan çerçevesinde Jean Piaget'nin epistemolojik yaklaşımına ve epistemolojinin konusunun, amacının, yönteminin ve diğer bilimlerle (daha özelde psikolojiyle) ilişkisinin ne olduğu gibi meta-epistemolojik konulara yaklaşımına odaklanabiliriz.

Jean Piaget kendi yaklaşımını, tam da bilgi kuramında psikolojistik tavrın güçlenmeye başladığı bir dönemde, yani yirminci yüzyılın ortalarından sonra ortaya koymuştu. Bu dönemlerde Piaget Genetik Epistemoloji (1970) yapıtında, genetik epistemoloji adını verdiği kendi yaklaşımını şu şekilde tanıtmıştır:

Genetik epistemoloji, bilgiyi, daha özelde bilimsel bilgiyi, onun tarihi, sosyogenetiği ve özellikle üzerine dayandĭ̆ kavramlar ve işlemler temelinde açıklama çabasıdır (Piaget 1970, 2).

Burada Piaget, genetik epistemolojinin bilgiyi, ağırlıklı olarak bilimsel bilgiyi soruşturarak açıklayacağını ima etmektedir. Bu noktada Piaget' in bu görüşü, bilgi fenomeninin en iyi şekilde ancak bilimsel bilginin oluşumunun incelenmesiyle açıklanabileceğini, çünkü "bilimsel bilginin en önemli ve ilginç bilgi türü” olduğunu ileri süren Karl Popper'ın (2002 [1959], 21-22) yaklaş1mına paraleldir. Genetik epistemoloji ifadesine gelindiğinde ise Piaget "genetik" sözcüğünü kökensel veya kökene dair anlamına gelecek şekilde kullanmaktadır. Diğer bir deyişle genetik epistemoloji, bilginin oluşumunun kökenine dair bir yaklaşımdır. Bu köken tarihsel köken olabileceği gibi toplumsal köken de olabilir. Ancak öyle görünüyor ki Piaget'nin genetik epistemoloji yaklaşımı açısından dikkate alınacak olan en önemli şey, bilimsel bilgiyi oluşturan kavram ve işlemlerin (bilindiği gibi işlem kavramı Piaget'nin gelişim psikolojisinde önemli bir teknik kavramdır) psikolojik kökenidir.

Piaget'nin genetik yaklaşımının analizine daha sonra geri dönülecektir. Ancak öncelikle Piaget'nin bu genetik yaklaşıma temel olan belirli bir bilgi anlayışına sahip olduğunu da not etmek gerekiyor. O halde genetik yaklaşımı daha iyi anlamak için öncelikle Piaget'nin bilgi anlayışını inceleyelim. Piaget, söz konusu bilgi tanımını şu şekilde sunmuştur:

Insan bilgisinin esasta aktif olduğunu düşünüyorum. Bilmek, gerçekliği dönüşüm sistemlerine asimile etmektir. Bilmek, belirli bir durumun nasıl meydana geldiğini anlamak için gerçekliği dönüştürmektir. (...) Gerçekliği bilmek, gerçekliğe daha fazla veya daha az yeterlilikte karşılık gelen dönüşüm sistemleri kurmak anlamina gelir. Onlar gerçeklikteki dönüşümlerle daha fazla veya daha az şekilde eşyapılıdır. Bilgiyi oluşturan dönüşüm yapıları gerçeklikteki dönüşümlerin kopyaları değil, deneyimin aralarından seçmemizi mümkün kildı̆̆ı olanaklı eşyapılı modellerdir. $O$ halde bilgi, sürekli olarak yeterli hale gelen dönüşüm sistemleridir (Piaget 1970, 15).

$\mathrm{Bu}$ tanım, bilim felsefesi açısından yaklaşıldığında, bilimin işlevinin dünyadaki durumları açıklamak olduğu şeklindeki çok klasik bir yaklaşıma (ki bu yaklaşımın birtakım rakipleri vardır) denk geliyor. Piaget'nin çerçevesinde açıklamak ise dünyadaki durumlara dair modeller (dönüşüm sistemleri) oluşturmak anlamına geliyor. Bu modeller durağan değil. Bilimde sürekli olarak, daha yetersiz modeller terk edilerek daha yeterli modeller oluşturuluyor. Böylece bilim ve dolayısıyla bilgi, sürekli olarak mantıksal düzenleme yoluyla bir yeniden kurma/oluşturma süreci içinde. Piaget, böyle bir bilim modelinden hareketle genel bir bilgi tanımına ulaşmış görünüyor. Bilgi insanın gerçekliğe dair yeterlilik/yetersizlik statüsüne "deneyimle” karar verdiği ve "sürekli olarak yeterli hale gelen” modelleri, Piaget'nin kendi terimiyle, dönüşüm sistemleridir. 
Bu noktada şu sorulabilir: Piaget'nin bilgi kavrayışına temel olan bu söz konusu bilim modeli sürekli devam eden bir mantıksal düzenleme sürecine (ve bu yolla bilginin ilerlemesine) dayanıyorsa burada, bilginin oluşumunu, daha doğrusu anılan mantıksal düzenleme sürecini anlamak için psikolojik soruşturmanın bir katkısının olacağı nasıl temellendirilebilir? Eğer sözü edilen düzenleme ve yeniden kurma süreci nihai olarak mantıksal bir süreçse, etkili bir epistemolojik soruşturma neden yalnızca mantıksal analize değil, buna ek olarak psikolojik analize de ihtiyaç duyar? Piaget'nin bu tür sorulara yanıtı şu şekilde sunulmuştur:

\section{Psikolojik görüş noktasindan ve genetik epistemolojik görüş noktasindan sorunumuz daha aşağl seviye bir bilgiden, daha ileri seviye sayllan bir bilgiye geçişin nasıl yapıldı̆̆ını açılklamaktır. Bu dönüşümlerin doğası olgusal bir sorundur. Bu dönüşümler tarihsel veya psikolojik veya (...) bazen biyolojiktir. Genetik epistemolojinin temel varsayımı bilginin man- tıksal ve rasyonel organizasyonu ile buna karşıllk gelen biçimlendirici psikolojik süreçler arasında bir paralellik olduğudur (Piaget 1970, 13).}

İşte, genetik psikoloji yaklaşımının psikolojik soruşturmayı, epistemolojik soruşturmanın önemli bir parçası haline getiren tezi tam da bu noktada yatıyor. Piaget'ye göre, (bilimsel) bilginin oluşumunda yapılan mantıksal düzenleme süreci ile insan bilişinde gerçekleşen bilişsel işlemler arasında bir paralellik bulunuyor. O halde bilgi kuramcılarının, bilgi fenomenini ve bilginin oluşumunu anlamak için yalnızca mantık bilimine ve mantıksal analize başvurması yeterli değildir. Bilginin söz konusu oluşum sürecini anlamak için mantıksal analize ek olarak, bilgiyi oluştururken kullanılan psikolojik "işlem” süreçlerinin kökenlerinin de incelenmesi çok önemlidir.

Şimdi bu temelden hareketle bilginin oluşumunun açıklanması hedefine yönelik olarak Piaget'nin genetik epistemoloji yaklaşımıyla teklif etmiş olduğu yöntem de genetik analiz, daha doğrusu, psikogenetik analizdir. Yani insanın bilgiyi oluştururken kullanmış olduğu bilişsel süreçlerin (daha özelde işlemlerin) kökenlerini ve bunların bilişsel gelişim dönemleri boyunca nasıl geliştiğini empirik psikolojinin verileriyle analiz etmektir. Piaget'nin genetik epistemoloji yaklaşımını tanımlarken kullandığı "bilgiyi özellikle üzerine dayandığı kavramlar ve işlemler temelinde açıklama çabası" ifadesinin anlamı budur. Genetik epistemoloji yaklaşımı, insanın bilgiyi oluşturma sürecinde kullanmış olduğu bilişsel süreçlerin veya işlemlerin psikogenetik analizi yapılmadan bilgi fenomeninin anlaşılamayacağını, hatta psikogenetik analizin epistemolojinin en öncelikli yöntemi olduğunu savunmaktadır.

Burada şunu da not etmek gerekiyor ki Piaget'nin, psikolojik soruşturmanın bu kadar önemli bir yer tuttuğu genetik epistemoloji yaklaşımını geliştirmesinin tek nedeni, yalnızca onun "bilginin mantıksal ve rasyonel organizasyonu ile buna karşıllk gelen biçimlendirici psikolojik süreçler arasında bir paralellik olduğu" kanaati değildir. Buna ek olarak önemli bir neden daha bulunmaktadır. Şöyle ki Piaget'ye göre bilgi kuramsal sorunların çözümünde psikolojik olgulara atıfta bulunmak aslında zaten hiç de yeni bir şey değildir. Yani, epistemolojik tartı̧̧malarda psikolojik olgulara atıfta bulunmak aslında, herhangi bir ek argümana gerek bile kalmadan, ister istemez epistemolojinin bir parçası haline zaten gelmiştir. Ancak Piaget'ye göre kendinden önceki bilgi kuramcılarının tartışmalarında sorunlu olan şey, bu bilgi kuramcılarının veya epistemologların anılan psikolojik olguların açıklamasına dair empirik deneylere başvurmaması, bir anlamda uzmanı olmadıkları konular hakkında yorum yapmış olmasıdır. Piaget bu konuda şu şekilde sitem etmiştir: 
Aslında bütün epistemologlar analizlerinde psikolojik unsurlara attfta bulunur; fakat psikolojiye atıfları çoğunlukla spekülatif olup psikolojik araştırmalara dayanmamaktadır. (...) Psikolojiyle ilgili şanssizlık şu ki herkes kendisinin bir psikolog olduğunu düşünür. Böyle bir durum fizik alanında veya felsefe alanında geçerli değil. Herkes kendini psikolog sayar. Bunun sonucunda bir epistemolog belirli bir psikolojik boyuttan bahsetmeye ihtiyaç duyduğunda psikolojik araştırmalara atıfta bulunmaz veya psikologlara danışmaz; kendi akll yürütmelerine dayanır. Ortaya çıkan psikolojik sorunu çözme girişiminde kendi düşüncesindeki birtakım fikirleri ve bağlantıları birleştirir (Piaget 1970, 11-12).

Böylece Piaget’nin kendinden önceki bilgi kuramsal tartışmalardan hoşnutsuzluğunun ve böylece genetik epistemoloji adını verdiği yaklaşımı geliştirmesinin başka bir nedeni, epistemolojik soruşturmalarda meslekten psikologların ve onların empirik verilerinin göz önünde bulundurulmamasıdır. O halde genetik epistemoloji yaklaşımının epistemolojiye getireceği yenilik yalnızca yeni bir bakış açısı (yani psikogenetik bakış açısı) değil aynı zamanda bu söz konusu psikolojik olgulara atıfların empirik uzmanlık temelinde bilimsel veriler ışığında yapılmasıdır. Kendisinin de ifadesiyle:

Genetik epistemolojinin ilk ilkesi psikolojiyi ciddiye almaktır. Psikolojiyi ciddiye almak ise psikolojik olgulara dair bir soru ortaya çıktığında, kişisel spekülasyonlar yoluyla bir çözüm icat etmek değil, psikolojik araştırmalara başvurmaktır (Piaget 1970, 9).

Diğer taraftan bu noktada ortaya çıkan bir sıkıntı bulunuyor. Piaget bilginin oluşumunun düzgün bir şekilde soruşturulabilmesi için psikolojik köken sorgulamasının (daha özelde psikogenetik analizin) öneminden bahsetmekle birlikte, bu noktada psikolojik soruşturmaların epistemoloji içindeki tam sınırının ne olduğu hala muğlak kalmaktadır. Diğer bir deyişle genetik epistemoloji yaklaşımına göre psikolojik soruşturmanın epistemolojik soruşturma içinde çok ciddi bir yeri olduğu anlaşılsa da bu yerin boyutları tam olarak açık değildir. Örneğin epistemoloji tamamen psikolojiye mi dayanır? Bu sorulara dair Piaget'nin yanıtı şu şekildedir:

Epistemolojinin yalnızca psikolojiye dayandı̆̆ izlenimi vermek istemiyorum. Aksine belirli bir biçimlendirmeyi yapabildiğimiz her zaman mantıksal biçimlendirme mutlaka esastır; düşüncenin gelişimi sürecinde belirli bir tamamlanmış yapıyla karşılaş̧tı̆ımı her zaman bu yapıyı biçimlendirmek için mantıkçılarla veya ilgilenmiş olduğumuz alandaki uzmanlarla iş birliği yaparız (Piaget 1970, 10).

Böylece Piaget, bilginin oluşumunu esasta sürekli devam eden bir yeniden düzenleme ve biçimlendirme süreci olarak kabul ettiği için, bilgi kuramının tamamen psikogenetik analize ve empirik psikolojinin sunduğu verilere dayanamayacağını, buna ek olarak söz konusu düzenleme sürecini soruşturmanın mantık alanındaki çalışmalara da dayanması gerektiğini ileri sürüyormuş gibi görünüyor.

Bütün bu verilerden hareketle Piaget'nin konuya yaklaşım biçimi hakkında şunlar söylenebilir. Piaget'nin genetik epistemoloji yaklaşımı apaçık şekilde psikolojistik bir yaklaşımdır. Çünkü bu yaklaşım, bilginin oluşumunu anlamak yolunda empirik psikoloji temelinde psikogenetik analizi, mantıksal analizden veya başka bir yöntemden daha önemli görür. Ancak, Piaget'nin psikolojizmi örneğin Quine'nın yaklaşımına benzer şekilde bilgi kuramını tamamen empirik psikolojinin bir alt dalı olarak konumlandıran katı psikolojistik bir yaklaşım da değildir. 
Onun yaklaşımı daha çok, bilginin sürekli bir yeniden düzenleme ve biçimlendirme içinde değişip ilerlediği, bu ilerlemenin incelenmesi sürecinin büyük oranda psikogenetik analiz yöntemine ve psikolojinin verilerine dayandığını, en azından psikogenetik analiz ve psikolojinin sağlayacağ 1 empirik veriler olmadan epistemolojinin sorunlarına hiçbir tatmin edici yanıt verilemeyeceğini; ancak bu ilerlemenin mantıksal temelleri de olduğu için bilgi kuramının tamamen psikolojinin bir alt dalı haline getirilemeyeceğini savunan daha 1lımlı bir tutuma işaret etmektedir. Böylece bütün bunların temelinde Piaget'nin epistemoloji-psikoloji ilişkilerine dair metaepistemolojik yaklaşımını bir tür ılımlı psikolojizm örneği olarak değerlendirebiliriz.

\section{II.}

Bu noktadan sonra artık, Jean Piaget'nin mantıksal pozitivistlere ve onların mantık ile matematiğin dile dayandığı tezine yönelttiği eleştirileri incelemeye başlayabiliriz. Ancak öncelikle onun bu eleştirisini özel kılan şeyin ne olduğunu açıklamakta fayda bulunuyor.

Jean Piaget, yapıtlarında, kendinden önceki bilgi kuramcılarını eleştirirken, bunu çoğunlukla ya bu bilgi kuramcılarının isimlerini paylaşmadan ya da paylaşmışsa bile bu kuramcıların herhangi bir yapıtına atıfta bulunmadan, genelleme yoluyla yapmıştır. Böylece onun önceki bölümde incelenen eleştirilerinde haklı olup olmadığını değerlendirebilmek de oldukça güçleşmektedir. Diğer taraftan tespit edilen bu sıkıntının önemli bir istisnası yirminci yüzyılın başında yapılan mantığın ve matematiğin temeli tartışmaları ve bu tartışmalara dair mantıksal pozitivistler tarafindan ileri sürülmüş olan mantık ve matematiğin dile dayandığı tezidir. Eşdeyiyle Piaget'nin kendinden önceki bilgi kuramcılarının empirik psikolojiye başvurmadan, ancak spekülasyon yoluyla psikolojik durumlara atıfta bulunduğunu ve genetik epistemoloji yaklaş1mının alana katkı sağlayacağını savunmak için gösterdiği en açık ve somut örnek, mantıksal pozitivistlerin söz konusu tezidir. Öyle ki Piaget mantıksal pozitivistlere yönelttiği bu eleştirisini hem matematik felsefecisi Evert Beth ile birlikte kaleme aldığ Matematiksel Epistemoloji ve Psikoloji (1966) adlı yapıtında, hem de Genetik Epistemoloji (1970) yapıtında sunmuştur. Şimdi söz konusu eleştiriyi inceleyelim. Öncelikle Piaget'ye göre:

Dil her ne kadar eksik olsa da (sınıflandırmalar, bağıntılar, bazı önermesel işlemler, niceleyiciler vb.) mantık içerir ve ek olarak doğal sayıların sözel serileri ve kesirler olarak bir aritmetik içerir. Bu bakımdan mantığı sıklıkla dil yoluyla açıklamış olmamız, ki bu açıklamalar matematiğin nominalist ve bazen uzlaşımsal bir yorumuna götürür, anlaşılırdır. Viyana Çevresi'yle başlayan mantıksal empirisizm, bu açıklama tarzını, biri sentetik (...) ve diğeri analitik (...) olan iki farklı doğruluk arasında radikal bir ayrım yaparak desteklemistir. Ardından Carnap analitik doğruları saf sentaksa indirgemeye çalışmış, ardindan Tarski'nin etkisiyle bir de semantik ekleme zorunluğu fark etmistir. Diğer taraftan Morris'in önerdiği gibi bir de pragmatik ekleme zorunluluğu hala tartışılmaktadır (Piaget 1966, 286).

Burada Piaget, mantıksal pozitivistlerin felsefesine dair bilindik hikayeyi paylaşmakta, onların mantığın ve matematiğin temellerine dair dilsel yaklaşımını bir tür nominalizm ve hatta uzlaşımcılık örneği olarak değerlendirmekte ve bu çerçevede mantıksal pozitivistlerden özellikle Rudolf Carnap'ı hedef aldığ 1 görülmektedir.

Diğer taraftan Piaget'ye göre mantığın ve matematiğin bilgisinin temelinin ne olduğu sorunu empirik psikolojinin verileri olmadan çözülemeyecek olgusal bir sorundur ve mantıksal pozitivistlerin mantığın ve matematiğin dile dayandığı tezi ise Piaget'ye göre psikolojinin 
verilerinin ciddiye alınmadığı bariz bir spekülasyon örneğidir:

\begin{abstract}
Mantıksal pozitivistler epistemolojilerinde psikolojiyi hiçbir zaman dikkate almamış; fakat mantıksal şeylerin ve matematiksel şeylerin dilsel yapılardan başka bir şey olmadı̆̆ını kabul etmiştir. (...) Konum, genel olarak mantıksal ve matematiksel gerçekliğin dilden türediğidir. Mantık ve matematik, özel dilsel yapılardan başka bir şey değildir (Piaget 1970, 8).
\end{abstract}

Ancak Piaget'ye göre empirik gelişim psikolojisinin verilerinin yardımıyla konuya yaklaşıld1ğında mantıkçı pozitivistlerin bu iddiası bilimsel verilerle uyuşmayan temelsiz bir iddiadır. Bunu savunmak için Piaget bir takım çeşitli argümanlar geliştirmiştir. Örneğin Piaget'nin argümanlarından birine göre, zeka geriliği veya bilişsel bozukluklar nedeniyle henüz bir dil öğrenememiş çocuklarda bile belirli bir seviyede mantıksal ve matematiksel düşünce (sayıları belirli bir sıraya koyabilme, küme kuramsal eșleștirme, sayısal nicelik fikri vb.) görülmektedir. Dolayısıyla, Piaget'nin kendi ifadesiyle, "dil edinmemiş çocuklarda dahi, iyi gelişmiş bir mantıksal düşünme bulunabilmektedir" (Piaget 1970, 46). Bu temelden hareketle Carnap ve mantıksal pozitivistlerin savunduğunun aksine mantıksal ve matematiksel düşünmenin temeli dil olamaz (Piaget 1970, 44-46).

Ancak Piaget'nin en fazla arkasında durduğu ve mantıksal pozitivistlerin iddiasını çürüttüğünü düşündüğü argüman bu değil. Piaget'ye göre bilişsel gelişim psikolojisi çerçevesinden insanda mantıksal ve matematiksel düşüncenin gelişimi ve bu gelişimin kökenleri incelendiğinde görülmektedir ki mantıksal ve matematiksel düşünce, çocukta, daha dil edinimi gerçekleşmeden önceki dönemde dahi ortaya çıkmaktadır. Diğer bir deyişle mantıksal ve matematiksel gelişim, dil ediniminden önce başlar. İşte en temelde bu noktadan hareketle, mantıksal pozitivistlerin ileri sürdüğünün aksine, mantık ve matematik bilgisinin dile dayandığı söylenemez. Piaget'nin kendi ifadeleriyle:

\title{
Mantıksal matematiksel yapıların sadece dilsel yapılardan türediği şeklindeki konuma karşı temel argüman şudur ki, bir bireyin zeka geli- şimi sürecinde mantıksal matematiksel yapılar dilin ortaya çıkmasından önce bulunmaktadır (Piaget 1970, 41).
}

Bunu savunmaya yönelik olarak Piaget çocuk gelişiminde mantıksal ve matematiksel düşüncenin duyusal-motor dönemde nasıl ortaya çıktığına, işlem öncesi dönemde nasıl geliştiğine (Piaget 1970, 41-57) ve somut ve soyut işlemler dönemlerinde bu düşünce sisteminin nasıll bir işlem yeteneği haline geldiğine (Piaget 1970, 21-40) dair psikolojik araştırmalar temelinde geniş açıklamalarda bulunmuştur. Şimdi bu açıklamaları ayrıntılarıyla incelemek bu çalışmayı elbette aşan bir uğraş olur; ancak bu açıklamalardaki önemli bazı noktalar şu şekilde sıralanabilir.

Öncelikle Piaget'nin belirttiği üzere bir çocukta dil edinimi ikinci yaşın başında veya ortalarına doğru başlıyor. Piaget bu dönemden önceki çocuklarda, birinci yaşın sonlarına doğru çocuğun eylemlerini yöneten belirli bir eylem mantığının geliştiğini ileri sürüyor (Piaget 1970, 41). Örneğin Piaget'ye göre bir oyuncağa ulaşmak için, oyuncağın üstünde durduğu örtüyü çeken çocukta belirli bir içerme bağıntısı mantığ bulunmaktadır. Çünkü bu eylem analiz edildiğinde, birbirlerine içerme bağıntısı ile bağlı olan pek çok alt şemanın oluşturduğu bir üst şema görünmektedir ve işte bu mantık esasta kümelerin birbirini içerebileceği şeklindeki matematiksel düşüncesinin ilkel bir biçimidir (Piaget 1970, 42). Benzeri şekilde Piaget'ye göre bu yaştaki çocuklarda bir küme kuramsal eşleme mantığı da bulunmaktadır. Örneğin, belirli bir modeli taklit eden bir çocukta, model ile taklit arasında bir eşleşme olduğu fikri zaten bulunmaktadır ve bu fikir aslında küme bilgimize de temel olan birebir eşleştirme işleminin çok ilkel bir biçimidir 
(Piaget 1970, 43). Böylece bu tür örnekler göz önünde bulundurulduğunda, Piaget'ye göre, çocukta ikinci yılın ortalarına doğru başlayan dil ediniminden önce dahi:

(...) duyusal-motor zekası içinde, mantıksal ve matematiksel yapılara temel olduğunu düşündüğüm belirli bir içerme mantı̆̆, belirli bir düzen mantığ ve belirli bir eşleştirme mantığı bulmaktayız. Bunlar elbette işlem değildir; ancak onlar daha sonra işlem haline gelecek başlangıçlardır (Piaget 1970, 43).

III.

Böylece bu görüşler temelinde Piaget, bilimsel verilere dayanarak çocukta mantıksal ve matematiksel düşüncenin kökenlerini psikolojik açıdan değerlendirdiğinde, mantığın ve matematiğin dile dayanamayacağını ileri sürmüştür. Ona göre mantıksal pozitivistlerin hatası ise empirik psikolojinin bu tür verilerinden haberdar olmadan açıklama geliştirmeye çalışmış olmalarıdır ki daha önceden de belirtildiği gibi "psikolojiyi ciddiye almadan" açıklama geliştirmeye çalışma hatası Piaget'ye göre bilgi kuramcıları arasında çok yaygındır.

Şimdi, Piaget'nin bu açıklamaları gerçekten dikkat çekicidir ve hem mantık ile matematik felsefesi alanında uzmanlaşan kişilerin hem de bilgi kuramı alanında çalışan kişilerin haberdar olması gereken açıklamalardır. Ancak bizim bu çalışmamız açısından Piaget'nin açıklamaları sonucu ortaya çıkan bir sorun bulunmaktadır. Sorun kısaca şu şekilde ifade edilebilir: Piaget'nin görüşlerini ve sunduğu empirik verileri yorumlama biçimini doğru kabul edersek gerçekten de mantıksal pozitivistlerin mantığın ve matematiğin dile dayandığı görüşünün spekülatif nitelikli ve çürütülmüş olduğunu kabul edebilir miydik?

Şimdi, Piaget konuya her ne kadar ilginç bir noktadan yaklaşmış olsa da bu soruya verilmesi gereken yanıt kesinlikle olumsuzdur. Bunun nedeni kısaca şu şekilde ifade edilebilir:

1. Mantıksal pozitivistlere (Carnap'a) göre: Mantık ve matematik dile veya dilsel uzlaşıma dayanır.

2. Piaget'ye göre: Mantık ve matematik tamamen dile veya dilsel uzlaşıma dayanmaz.

$\mathrm{Bu}$ iki karşıt tezde Piaget ve mantıksal pozitivistler'in (Carnap'ın) "mantık ve matematik" ifadesinden ve ek olarak "dil" ifadesinden anladıkları şey aynı olsaydı, burada ikinci görüş birinci görüşü elbette çürütürdü. Ancak bu iki grubun söz konusu tezlerinde hem "mantık ve matematik" ifadesinden hem de "dil" sözcüğünden anladıkları farklıdır. Dolayısıyla Piaget'nin görüşleri, düşündüğünün aksine, mantıksal pozitivistlerin görüşünü esasta çürütmez. Şimdi bu noktayı açalım.

Öncelikle Carnap'ın mantığın ve matematiğin dile veya dilsel uzlaşıma dayandığı görüşü, ki Carnap sonraları bu ifadenin mantıksal pozitivistlerin mantık ve matematik kavrayışını esasta tam olarak formüle edemediğini ileri sürmüştür (Carnap 1963, 915-916), en azından Carnap'ın ileri sürdüğü haliyle, bireyde mantıksal ve matematiksel düşüncenin nasıl geliştiğine ilişkin bir tez değil, bilimde kullandığımız mantıksal ve matematiksel yöntemlere hangi temelde güvenebileceğimize ilişkin bir tezdir ve bu tez daha genel bir sorun olan "bilimin geçerliliğinin ölçütü” sorunuyla ilişkilidir. Carnap, bilimin geçerliliğini bilimsel soruşturmaların ve bilimi oluşturan cümlelerin anlamlılı̆̆ında ve bilim dışı her soruşturmanın ise anlamsızlığında gören Wittgenstein geleneğinden etkilenmiş bir düşünürdür. Bilimi oluşturan yargıların, örneğin kuramların anlamlılığı ise bu cümleleri empirik olarak olumlayan veya değilleyen şartların açıklı̆̆nda yatar. Bu görüşün altında yatan fikir, çoğu zaman doğrulanabilirlik temelli anlam ölçütü veya kısaca doğrulanabilirlik ölçütü olarak bilinen görüştür (bk. Aslan 2016). Carnap bu noktayı şöyle ifade eder: 
Bilgi kuramının iki temel sorunu, anlam sorunu ve doğrulama sorunudur. Birinci sorun bir cümlenin hangi şartlar altında bilişsel veya olgusal anlamda anlaml olduğu sorunudur. İkinci sorun ise bir şeyi nasıl bilebildiğimiz, bir cümlenin doğru veya yanlış olduğunu nasıl bulabileceğimiz sorunudur. İkinci sorun birincisine dayanır. Şu açık ki, bir cümlenin doğru olup olmadığını bulmak için önce cümleyi anlamak, yani anlamını bilmek zorundayız. Ancak empirisizm açısından konuya yaklaşıldiğında bu iki sorun arasında daha yakın bir ilişsi bulunmaktadır. Bu iki sorunun belirli bir anlamda yalnızca tek yanitı bulunur. Bir cümlenin doğru olduğunu bulmak için gerekli olan şeyi biliyorsak, anlamını da biliyoruz demektir (Carnap 1936, 420)

$\mathrm{Bu}$ ölçüt temelinde bilimi oluşturan yargıların ve böylece bilimin anlamlılı̆̆ı, onların ilkece hangi empirik şartlar altında doğru olup olmadığını bilmemize dayanır. Carnap'ın epistemolojiye verdiği görev ise bilimdeki bu anlamlılığı korumak, hatta anlamda açıklığı en üst mertebeye çıkarmak, böylece bilimin temellerini güvence altında tutmaktır. Onun epistemolojinin en temel iki sorununun anlam ve doğrulama sorunu olduğunu ileri sürmesinin nedeni de budur. Bilimi oluşturan cümlelerin anlamlarının açık kılınması ise bilimsel cümlelerin analizi yoluyla sürdürülmesi gereken bir projedir. Analizle yapılacak şey bilimi oluşturan kuramlardan deneyim yoluyla sınanacak olan hipotezleri en açık şekilde ortaya çıkarmaktır. Böylece bu kuramları sınamak için hangi hipotezleri sınamamız gerektiği sabitlenmiş olur. Söz konusu analizin yöntemi ise dilin daha doğrusu bilim dilinin mantıksal analizidir (Carnap 1966 [1935], 207217). Çünkü bir kuramı hangi hipotezler ışığında sınayacağımızı bilmek için öncelikle kuramı anlamalıyız ve bunun gerek şartlarından biri, doğal olarak kuramın içinde ifade edildiği dili bilmekten geçer. Carnap'ın düşüncesine göre kuramı ifade ettiğimiz cümle veya cümleler kümesi ile bu kuramdan çıkan hipotezleri ifade ettiğimiz cümleler arasındaki mantıksal ve matematiksel bă̆, kısaca çıkarım bă̆l, nihai olarak bu kuram veya hipotezleri ifade ettiğimiz dil içinde kurulur. Aynı durum, kuram ile kuramı kendisinin yoluyla sınadığımız hipotezi olumlayan veya değilleyen deneyimi ifade ettiğimiz cümleler arasındaki ilişkide de geçerlidir. Dolayısıyla Carnap'ın ileri sürdügü anlamda "mantık ve matematik dile dayanır" tezi, herhangi bir kişinin bilişsel gelişim süreci içinde geliştirdiği mantığın değil bilimsel gerekçelendirmenin mantığının dile dayanmasıdır. Daha da doğrusu bilimsel kuramları içinde ifade ettiğimiz dil içinde kurulmasıdır. Hatta bu anlamda Carnap'a göre, bilimi içinde ifade ettiğimiz dili değiştirmek de, mantığı, daha özelde bilimin mantığını değiştirmektir.

İkinci olarak belirtildiği gibi Piaget'nin "mantık ve matematik dile veya dilsel uzlaşıma dayanır" ifadesinde "dil" sözcüğünden anladığı ile Carnap'ın bu sözcükten anladığı da birbirinden farklı şeylerdir. Burada özellikle uzlaşımcılık (İng. conventionalism) terimi üzerine odaklanmak gerekiyor. Piaget pek çok yerde mantıksal pozitivistlerin ve onları destekleyenlerin konuya yaklaşımını bir uzlaşımcılık örneği olarak değerlendirmiştir (Piaget 1966, 286-287; 1970, 10). Ancak uzlaşımcılık terimi, Nelson Goodman ve Michael Rescorla'nın da ifade ettiği gibi, şu anlamda sıkıntılı bir terimdir ki, bu terimin geçmişte zaten olan pratik hakkında mı, yoksa gelecekte olması gereken pratik hakkında mı ileri sürüldüğü her zaman kafa karışıklığına yol açar (Rescorla 2015). Daha önce de belirtildiği gibi, bilimi gerekçeli veya temelleri sağlam kılan şeyin bilimin anlamlılığında yattığını düşünen Carnap, bu anlamlılığı korumak ve anlamdaki açıklığın en yüksek mertebeye ulaşması bilimsel kuramları içinde formüle edebileceğimiz ve onlar üzerinde yapılacak analizi de içinde formüle edebileceğimiz bir bilim dili (tercihen yapay bir biçimsel bilim dili) geliştirilmesi gerektiğini düşünmüştür. Diğer bir deyişle Carnap'ın 
anladığ 1 anlamda uzlaşımcılık, hem geleneği, hem de doğal dili bir kenara bırakarak, bilimi gelecekte içinde formüle edebileceğimiz bir dilde uzlaşmak anlamında bir uzlaşımcılıktır. Bu ise onun Dilin Mantıksal Sentaksı (Carnap 2001 [1934]) yapitı ve ondan sonraki yapitlarında, önceleri sentaktik, sonraları semantik temelde (örneğin: Carnap 1939) sürdürmüş olduğu ünlü bilim dilinin akıl temelinde yeniden inşası veya kısaca rasyonel yeniden inşa (İng. rational reconstruction) projesidir. Böylece kısaca Carnap'ın iddiasına temel olan dil, bireyin bilişsel gelişimi sürecinde sosyokültürel çevresinde öğrenmiş olduğu ve toplumsal uzlaşıma dayanan doğal dil değil, bilimi ve bilimin içindeki delil-kuram ilişkilerini gelecekte içinde formüle edebileceğimiz yapay bir biçimsel bilim dilidir. Bunların sonucu olarak Piaget'nin mantıksal ve matematiksel yapıların ve düşüncenin çocukta ne zaman ve nasıl ortaya çıkmaya başladığı ve nasıl geliştiğine dair açıklamaları bilimsel veri olarak kabul edilse dahi, bu açıklamaların Carnap'ın görüşlerini ne çürüttüğü ne de spekülatif kıldığı söylenebilir. Bu düşünürlerin düşüncelerini ifade ettikleri sözcükler aynı olsa da söz etmiş oldukları kavramlar farklı kavramlardır.

Belirli bir uslamlama biçiminin veya bir mantık kuralının bireyin bilişsel gelişim süreci içinde nasıl ortaya çıktığını ve geliştiğini incelemek betimsel bir konuyken, bu uslamlama biçiminin veya mantıksal çıkarım kuralının gerekçeli, savunulabilir veya temelinin sağlam olup olmadığını incelemek normatif bir konudur. Epistemoloji açısından önemli olan sorunlar ise her zaman normatif sorunlar olmuştur. Diğer bir deyişle mantığın ve matematiğin (epistemik) temeli tartışmaları, esasta bilim sürecinde kullanmış olduğumuz mantıksal ve matematiksel yöntemlerin iyi yöntemler olduğuna hangi temelde inanabileceğimize dair normatif tartışmalardır. Carnap'ın tezi de esasta bu çerçeve içinde ileri sürülmüş normatif bir yaklaşımdır: Şu an kullandığımız ve gelecekte kullanacağımız mantıksal ve matematiksel yöntemlere olan güvenimizin temelinin ne olduğu sorununa bu tez, bilimde basitlik sağlayıp sağlamadıkları, uygulama alanı bulup bulamadıkları, bilim dili oluşturmak açısından yararlı olup olmadıkları ve bunun gibi bir takım pragmatik hassasiyetler gözetilerek ulaşılacak uzlaşım yanıtını verir (Carnap 2001 [1934], 320; 1939, 28-29). Sonuç olarak Piaget'nin Carnap'a yönelttiği eleştirideki asıl sorun, Piaget'nin epistemolojik sorunlardaki bu normatif boyutu gözden kaçırmış olmasıdır (Piaget'nin, Carnap'ın yaklaşımı hakkındaki bu karışıklığı daha önce Siegel 1978'de de tespit edilmiştir).

$\mathrm{Bu}$ temellerden hareketle psikogenetik yaklaşımla Carnap'ın ve mantıksal pozitivistlerin kuramına veya başka bir klasik normatif kurama gerçekten rakip bir kuram geliştirildiğinden söz edebilmek için, betimsel değil, normatif bir tez ortaya koyulmalıdır. Diğer bir deyişle, genetik epistemoloji çerçevesi içinden, bireyin bilişsel gelişiminde mantığın ve matematiğin gelişiminden yola çıkarak, bilimde kullandığımız mantıksal ve matematiksel yöntemlere olan güvenimizin kaynağına doğru bir çıkarım yapılabilmelidir.

Şimdi, çalışmayı bitirmeden önce bu konu üzerine de bazı notlar düşmenin faydası bulunuyor. Günümüzde genetik epistemoloji veya benzeri bir yaklaşımı savunan bir kişi bu tür normatif sorunlara nasıl yanıt verebilir? Piaget'nin yapıtlarına bu açıdan bakıldığında onun bu tür sorulara doğrudan yanıt vermemiş olduğu görülüyor. Diğer taraftan onun uzlaşımcılık yaklaşımına dair genel bir eleştirisinde bu normatif konulara dair dolaylı da olsa küçük bir yanıt bulmak mümkündür. Bu eleştiride Piaget mantıktaki çelişmezlik ilkesine güvenimizin kaynağ hakkında şunları belirtmiştir:

(...) bir seçimin mümkün olmadĭ̆ı müddetçe uzlaşımcılık teriminin anlamını kaybettiği sıklıkla gözlenmektedir. Şimdi, ĕger biçimsel çelişmezlik ilkesi yalnızca uzlaşımsal olsaydl, somut ve hatta duyumotor 
bağdaşım biçimlerini, ki bunlar çelişmezliğin ilk başlangıçlarıdır, açıklamak zor olurdu. Örneğin yiyecek peşinde koşmak uyumsuz ve çelişik hareketler gerektirseydi, yaşayan bir varlı̆̆n nasll hayatta kalabildiğini görmek zor olurdu: Bu nedenle, ne kadar ilkel olursa olsun, bir çelişmezlik biçimi gerektiren her seviyeden koordinasyonlar olmasaydl, yaşam dünya yüzeyinden çoktan yok olmuş olurdu ve uzlaşımcilığı savunan kimse de kalmazdl (Piaget 1966, 290).

Piaget bu eleştiriyi doğrudan Carnap'a ve mantıksal pozitivizme değil ancak genel olarak uzlaşımcı yaklaşımlara yöneltmiştir ve karşılgusal (İng. counterfactual) yapıdaki bu kısa iddia yardımıyla Piaget, bireyde mantığın gelişiminden yola çıkarak mantıksal yöntemlerimize olan güvenimizin temeline, betimsel epistemolojiden normatif epistemolojiye, köken sorunundan temeller sorununa, gelişim psikolojisinden normatif epistemolojiye doğru bir çıkarım yapmış görünmektedir. Şöyle ki, bu çıkarıma göre bizim biçimsel çelişmezlik ilkesinin iyi bir ilke olduğuna güvenimiz, başka bir alternatifimizin olmamasındandır ve başka bir alternatif olmamasının nedeni ise bilişsel gelişim süreci içinde eylemlerimizi ve zihin yapılarımızı koordine etme biçimimizin, ki bu koordinasyon nihai olarak hayatta kalmaya hizmet eder, bizi çelişmezlik ilkesinden başka bir ilkeye götürmemesidir. Böylece sonuç olarak çelişmezlik ilkesine olan güvenimizin kaynağı, nihai olarak bizi hayatta tutmasındadır. Diğer taraftan bu açıklamanın ne kadar kuvvetli bir açıklama olduğu tartışılır durumdadır. Çünkü öncelikle her ne kadar Piaget'nin genetik epistemoloji yaklaşımını ortaya koyduğu zamanlarda çelişmezlik ilkesine bir alternatif olmasa da, çok kısa bir süre sonra tutarlılıkötesi mantık (İng. paraconsistent logics) yaklaşımı, öncelikle Latin Amerika ülkelerinden başlayarak dünyanın her yerinde tanınır olmaya başlamıştı. Bu mantık, çelişmezlik ilkesinin en temel gerekçesi olan "çelişkili öncüllerden her sonuç çıkar" savını reddetmiştir ve savunucuları bu mantık sisteminin bilimde çeşitli şekillerde (örneğin yapay zeka çalışmalarında, küme kuramında, epistemolojide bir kanaatin ne zamana kadar benimsenip ne zaman terk edilmesi gerektiği konulu inanç revizyonu tartışmalarında vb.) uygulama alanı bulabileceğini ciddi şekilde savunmuştur (bk. Bueno 2010; Priest 2015). Bundan daha da önemlisi şudur ki, bilime ve metodolojisine temel olan her mantıksal yönteme güvenimizin kaynağını bu şekilde açıklamak bir miktar sıkıntılı olabilir. Örneğin Piaget, genetik epistemoloji yaklaşımıyla özellikle "bilimsel bilgiyi" açıklama hedefinde olduğunu ileri sürmektedir. Ancak bilim adamları kullandıkları mantıksal ve matematiksel yöntemlere, kendilerini hayatta kalmaya hizmet eden kanaatlere ulaştırdığını düşündükleri için mi, yoksa doğru kanaatlere ulaştırdığını düşündükleri için mi güvenir? Bilim adamları mantıksal ve matematiksel metodolojilerini hangi temelde savunur? Piaget'nin uzlaşımcılığa yönelttiği bu eleştiri, bilim sürecini dünyaya dair doğru kanaatler geliştirme sürecinden çok, bir tür adaptif veya hayatta kalmaya hizmet eden kanaatler geliştirme sürecine çevirmez mi? Şimdi bu tür noktalara işaret etmenin nedeni Piaget'nin yaklaşımını eleştirmek değildir. Kaldı ki Piaget'nin bu küçük iddiası mantığın ve matematiğin temellerine dair kapsamlı bir kuram olması amacıyla da ortaya koyulmamıştır. Diğer taraftan Piaget'nin genetik epistemoloji yaklaşımı, bugün psikoloji alanında hala canlı bir yaklaşımdır ve belki de savunucuları, gelişim psikolojisinden yola çıkarak normatif epistemolojiye doğru bir bağ kuran bu küçük açıklamadan yola çıkarak, ileri sürdüğümüz türden olası reaksiyonları da dikkate alarak, mantığın ve matematiğin temellerine dair klasik normatif kuramlara karşı gerçek anlamda rakip olacak bir kuram geliştirebilir.

\section{Sonuç}

Böylece bu çalışmada epistemolojinin önemli tartışma konularından biri olan mantığın ve matematiğin temelleri konusuna Jean Piaget'nin genetik epistemoloji adını verdiği meta- 
epistemolojik çerçeveyle nasıl yaklaştığı incelendi. Bu incelemenin sağlıklı yapılabilmesi için söz konusu genetik epistemoloji çerçevesinin ne olduğu, psikoloji-epistemoloji ilişkilerine dair bir takım genel yaklaşımlarla karşılaştırıldığında nasıl bir konuma denk geldiği, alandaki hangi eksiklikler göz önünde bulundurularak ortaya koyulduğu, alana ne türden bir katkı sağlayacağının amaçlandığı ve benzeri konular da dikkate alındı. Bu inceleme sonucunda, Piaget'nin kendinden önceki bilgi kuramcılarının yaklaşımlarının bilimsel temeli olmayan spekülatif yaklaşımlar olduğunu göstermek için ileri sürdüğü en somut örnek olan Carnap ve mantıksal pozitivistlerin mantığın ve matematiğin dile dayandığı görüşüne yaptığı eleştiride haksız olduğu görülmektedir. Çünkü Piaget, Carnap'ın temelde bilimde kullandığımız mantıksal ve matematiksel yöntemlere güvenimizin ve kuram ile hipotez arasındaki çıkarımsal bağın kaynağına dair bir görüş olan bu normatif kuramı, hatalı olarak bilimin bu anlamda mantığının ve matematiğinin sosyokültürel uzlaşım sonucu gelişmiş olan dile dayandığı şeklindeki bir kuram olarak değerlendirerek eleştirmiştir. Bunun sonucunda, Piaget'nin bu kurama rakip olarak ileri sürdüğü bilimsel açıklamalar da, her ne kadar çok değerli olsalar da, söz konusu normatif karakterli epistemolojik sorunla doğrudan bağlantısı olmayan açıklamalardır. Dolayısıyla genetik epistemoloji yaklaşımının mantığın ve matematiğin temeli sorununa dair klasik normatif kuramlara rakip olacak bir kuram ortaya koyabilmesi için, mantığın ve matematiğin bireyin gelişiminde nasıl ortaya çıkıp geliştiğinden yola çıkarak, bilimde kullandığımız mantık ve matematiğe hangi temelde güvenebileceğimize dair kapsamlı bir kuram ortaya koyabilmesi gerekmektedir.

\section{KAYNAKÇA}

Aslan H. (2006). "Doğrulanabilirlik İlkesi”. Felsefe Ansiklopedisi. Cilt IV. Ankara 2006.

Bueno O. (2010). "Philosophy of Logic”. Ed. Fritz Allhoff, Philosophies of Sciences. Oxford 2010.

Carnap R. (1936). “Testability and Meaning”. Philosophy of Science 3/4 (Ekim 1936) 419-471.

Carnap R. (1939). "Foundations of Logic and Mathematics". International Encyclopedia of Unified Science 1/3 (1939) 1-71.

Carnap R. (1966 [1935]). "Rejection of Metaphysics”. Ed. Morris Weitz, 20th-Century Philosophy: The Analytic Tradition (1966) 206-219. New York.

Carnap R. (2001 [1934]). The Logical Syntax of Language. London 2001.

Kornblith H. (2010). "Naturalized Epistemology”. Eds. Jonathan Dancy, Ernest Sosa \& Matthias Steup, A Companion to Epistemology. Oxford $2010^{2}$.

Popper K. (2002 [1959]). Logic of Scientific Discovery. London 2002.

Piaget J. \& Beth E. W. (1966). Mathematical Epistemology and Psychology. Dordrecht 1966.

Piaget J. (1970). Genetic Epistemology. New York 1970.

Priest G., Tanaka K. \& Weber Z. (2015) “Paraconsistent Logic”. Ed. N. Z. Edward, The Stanford Encyclopedia of Philosophy. Source: http://plato.stanford.edu/archives/spr2015/entries/logicparaconsistent/

Quine W. V. O. (1992). Pursuit of Truth. Cambridge $1992^{2}$.

Quine W. V.O. (1969). "Epistemology Naturalized”. Ontological Relativity and Other Essays (1969). New York.

Rescorla M. (2015) “Convention”. Ed. N. Z. Edward, The Stanford Encyclopedia of Philosophy. Source: http://plato.stanford.edu/archives/sum2015/entries/convention

Russell B. (1904). "Meinong's Theory of Complexes and Assumptions (I.)”. Mind 13/50 (April 1904) 204-219.

Siegel H. (1978). “Piaget’s Conception of Epistemology”. Educational Theory 28/1 (1978) 16-22. 